\title{
Short Communication: Effect of Changing the Ratio of Forage to Concentrate on Ammonia Emissions by Dairy Heifers ${ }^{1}$
}

\author{
G. J. Lascano, ${ }^{*}$ G. I. Zanton, ${ }^{*}$ M. L. Moody, ${ }^{*}$ P. A. Topper,† E. F. Wheeler,† and A. J. Heinrichs ${ }^{* 1}$ \\ *Department of Dairy and Animal Science, and \\ †Department of Agricultural \& Biological Engineering, The Pennsylvania State University, University Park 16802
}

\begin{abstract}
Two animal growth studies and a companion digestibility study were conducted to evaluate the effect of differing ratios of forage to concentrate and the addition of yeast culture (Saccharomyces cerevisiae) on $\mathrm{NH}_{3}$ emissions from the manure of growing dairy heifers with corn silage (CS) as the sole forage. Flux chamber methods were used to measure $\mathrm{NH}_{3}$ volatilization from the barn floor or by laboratory procedures. In experiment 1, 24 Holstein heifers $(159 \pm 3.3 \mathrm{~kg}$ of initial body weight; BW) were fed either a low-concentrate diet (LC; $77 \%$ CS, 23\% concentrate) or a high-concentrate diet (HC; $33 \% \mathrm{CS}, 67 \%$ concentrate) in a randomized design. Manure (feces and urine mixture) from heifers consuming the LC diets volatilized similar amounts of $\mathrm{NH}_{3}$ as manure from $\mathrm{HC}$ heifers (314.0 vs. $174.4 \pm$ $36.1 \mathrm{\mu g} / \mathrm{cm}^{2}$ per min). In experiment 2, 24 older heifers $(227.9 \pm 27.1 \mathrm{~kg}$ of BW) were used. Manure from HC heifers released slightly less $\mathrm{NH}_{3}$ from the barn floor, confirming the results from the initial study. Finally, a digestibility study was undertaken using four 9-mo-old heifers (234 $\pm 15 \mathrm{~kg}$ of initial BW) and four 14-mo-old heifers ( $409 \pm 20 \mathrm{~kg}$ of initial BW), allocated to 4 treatments consisting of an $\mathrm{HC}$ or LC diet with or without yeast culture addition. Emissions per unit of manure (mg of $\mathrm{NH}_{3} / \mathrm{g}$ ) from heifers in both age groups were greater for the HC diets; however, total emissions per day were equal. Yeast culture addition had no effect on cumulative daily emissions. In these 3 experiments, $\mathrm{NH}_{3}$ emissions from $\mathrm{HC}$ heifers were not different from those from LC heifers.
\end{abstract}

Key words: ammonia emission, dairy heifer, yeast culture, forage:concentrate

Environmental policies and regulations are having an increasing impact on animal production. Dairy

Received March 13, 2008

Accepted July 2, 2008.

${ }^{1}$ This research is a component of NC-1042: Management Systems to Improve the Economic and Environmental Sustainability of Dairy Enterprises.

${ }^{2}$ Corresponding author: ajh@psu.edu and beef cattle emit approximately $50 \%$ of the $\mathrm{NH}_{3}$ released to the environment from agricultural sources in the United States (Battye et al., 1994). Currently, USDA estimates the US dairy replacement population (heifers of $\mathrm{BW} \geq 227 \mathrm{~kg}$ ) at approximately 4 million, or $4 \%$ of the total dairy and beef cattle inventory (USDA, National Agricultural Statistics Service, 2007; based on 6 reports from 2005 to 2007). Dietary manipulation has been proven to affect the composition of manure excreted and $\mathrm{NH}_{3}$ emissions (James et al., 1999; Misselbrook et al., 2005). Three trials were conducted to assess the effect of manipulating the ratio of forage to concentrate $(\mathbf{F}: \mathbf{C})$ on $\mathrm{NH}_{3}$ volatilization from manure produced by growing dairy heifers.

In 2 growth studies, 48 total heifers (experiment 1: 24 animals, $158.9 \pm 21.4 \mathrm{~d}$ of age and $159 \pm 3.3 \mathrm{~kg}$ of initial BW; experiment 2: 24 animals, $246.5 \pm 50.2 \mathrm{~d}$ of age and $227.9 \pm 27.1 \mathrm{~kg}$ of initial BW) were cared for according to a protocol approved by The Pennsylvania State University Institutional Animal Care and Use Committee. Heifers from the university herd were randomly assigned to 4 different pens and blocked according to age and sire in the first experiment and according to BW in the second. Pens of 6 heifers and 5 or 7 heifers in the first and second experiments, respectively, were then randomly assigned to either a high-concentrate (HC) or low-concentrate (LC) treatment by using a complete block design. Heifers remained in the same treatment group for 154 and $133 \mathrm{~d}$ in experiments 1 and 2, respectively. They were housed in a naturally ventilated barn with free access to water and were bedded with sand and sawdust. Heifers were fed twice daily at 0700 and $1900 \mathrm{~h}$ in the first trial and once a day at $0800 \mathrm{~h}$ in the second. Animals had individual access to feed by using the Calan Broadbent Feeding System (American Calan, Northwood, NH). Nutrient composition of feedstuffs and TMR was analyzed according to the procedures used by Moody et al. (2007). Animal BW was measured weekly approximately $1 \mathrm{~h}$ before feeding on 2 consecutive days per week.

Dairy heifers housed in naturally ventilated freestall barns released $\mathrm{NH}_{3}$ to the environment from the deposition of manure on the floor. Scraping occurred 
once a day or every other day. A practical method to measure ammonia released to the environment is the use of portable flux chambers (Blanes-Vidal et al., 2007).

In Experiments 1 and 2, ammonia volatilization was measured from the manure accumulated on the surface of the barn floor by using a portable flux chamber. On the first day of data collection, manure was scraped from the pens, and then approximately $3 \mathrm{~h}$ later, $\mathrm{NH}_{3}$ emission data collection commenced. During the next $36 \mathrm{~h}$, manure was not scraped, but flux chamber data collection occurred. This allowed manure from the heifers in each pen to accumulate on the barn floor. Five periods of $36 \mathrm{~h}$ each were measured for both experiments 1 and 2. For experiment $1, \mathrm{NH}_{3}$ concentration was determined by using a portable non-steady-state flux chamber, multigas analyzer technique (Blanes-Vidal et al., 2007). This flux chamber method did not have internal air recirculation, and further testing revealed that to estimate emissions from the barn accurately, a correction factor was needed. Measured emission rates were multiplied by a factor of 7.9 to correct for the exclusion of wind velocity (Blanes-Vidal et al., 2007). During experiment 1,9 locations were selected in the scraped portion of the pen that minimized gravity-flow manure or urine cross-contamination from other pens, feed, and bedding.

Experiment 2 used an improved airflow recirculation portable flux chamber to offer a more uniform internal air velocity (Wheeler et al., 2007b). Again, only the scraped portion of the pen was used for gathering emission data, but the flux chamber locations were more uniformly located across the pen. Liquid cross-contamination from other pens was prevented by constructing dams between pens on the sloped floor. For experiments 1 and 2, each pen was divided into 9 symmetric sampling squares that were measured at 8 different times throughout the 36 -h sampling period. In the first experiment, the area of the alley of all 4 pens was $17.28 \mathrm{~m}^{2}$, and in the second experiment two $17.28 \mathrm{~m}^{2}$ and two $20.18 \mathrm{~m}^{2}$ pens were used.

In a companion digestibility trial (experiment 3), 8 Holstein heifers were selected from 2 different age groups (4 heifers/group), referred to as young (288 \pm $4.5 \mathrm{~d}$ of age; $234 \pm 15.3 \mathrm{~kg} \mathrm{BW})$ and old $(410 \pm 2.2 \mathrm{~d}$ of age; $409 \pm 20.3 \mathrm{~kg}$ of BW). Dry matter intakes were estimated by using NRC (2001) guidelines and were formulated to attain $0.22 \mathrm{Mcal}$ of $\mathrm{ME} / \mathrm{kg}$ of empty $\mathrm{BW}^{0.75}$ and provide $800 \mathrm{~g} / \mathrm{d}$ of ADG (Moody et al., 2007). Heifers were individually housed in tie stalls in an environmentally controlled barn with continuous access to fresh water. Treatments in experiment 3 were arranged as a $2 \times 2$ factorial: $\mathrm{HC}$ and $\mathrm{LC}$ with or without yeast culture (YC; Yea-sacc ${ }^{1026}$, Alltech Inc., Nicholas- ville, $\mathrm{KY}$ ), which was top-dressed at the time of feeding ( $1 \mathrm{~g}$ of $\mathrm{YC} / \mathrm{kg}$ of intake, as-fed basis). Treatments were administered according to a split-plot Latin square design, with heifer age as the whole plot and treatment as the subplot, and were fed for four 21-d periods ( $17 \mathrm{~d}$ of adaptation, $4 \mathrm{~d}$ of total collection). Ingredients and nutrient composition of treatment rations are given in Table 1 for the 3 experiments.

Urine was collected by using noninvasive urinary devices modified from the device of Fellner et al. (1988). Subsamples of $250 \mathrm{~mL}$ of urine were collected without acidification for the analysis of $\mathrm{NH}_{3}$ emissions; the remaining urine was acidified by addition of $12 \mathrm{~N} \mathrm{HCl}$ to maintain $\mathrm{pH}$ below 3. Urine and feces were weighed and subsampled every $24 \mathrm{~h}$ at $1000 \mathrm{~h}$. Acidified urine samples were analyzed for urea N (catalog no. 0580250, Stanbio Laboratory, Boerne, TX).

Ammonia emissions in experiment 3 were analyzed by using 6 benchtop, steady-state (dynamic) flux chambers under controlled conditions (Wheeler et al., 2007a). In brief, the dynamic chamber setup used a photoacoustic sensor (model 1412, Innova, Ballerup, Denmark), to monitor gas concentrations every 20 min for a 24 -h period. Data from samples of 5 different heifers were collected in 2 separate 24 -h periods (5 heifers/24-h period). A repetition of a random fifth heifer was used as an emission control. Five of the 3.8-L glass jars contained 200 g of manure slurry (feces and urine) combined at the initiation of the $\mathrm{NH}_{3}$ emission test, representing the ratio of feces to urine excreted. Total feces and urine excretion from the first $2 \mathrm{~d}$ of each period were used to determine the fecesto-urine ratio (wet basis) for each heifer. The sixth jar contained distilled water as a control, a check for crosscontamination of sampling lines and for determining background $\mathrm{NH}_{3}$ levels. The non-steady-state flux chamber used during measurements in experiment 1 was a first-generation design following an EPA protocol, but during use and follow-up testing it proved to underestimate the true emission rate. A correction factor was developed to better express measured emission rate to true emission rate. During experiment 2 , the second-generation flux chamber that was developed to more accurately determine the true emission rate was used; thus, no correction factor was needed. For experiment 3, a steady-state, multichamber flux chamber was used that monitored emission rates from the moment the urine and feces were mixed in the chambers up to $24 \mathrm{~h}$ of data collection.

All statistical analysis were conducted in SAS (SAS Institute, Cary, NC) with the MIXED procedure. Because pen was considered the experimental unit, both growth trials were analyzed as a completely randomized design, with the model: 
Table 1. Ingredient and nutrient composition of high (HC) or low (LC) concentrate diets fed to Holstein heifers in 3 ammonia emissions experiments

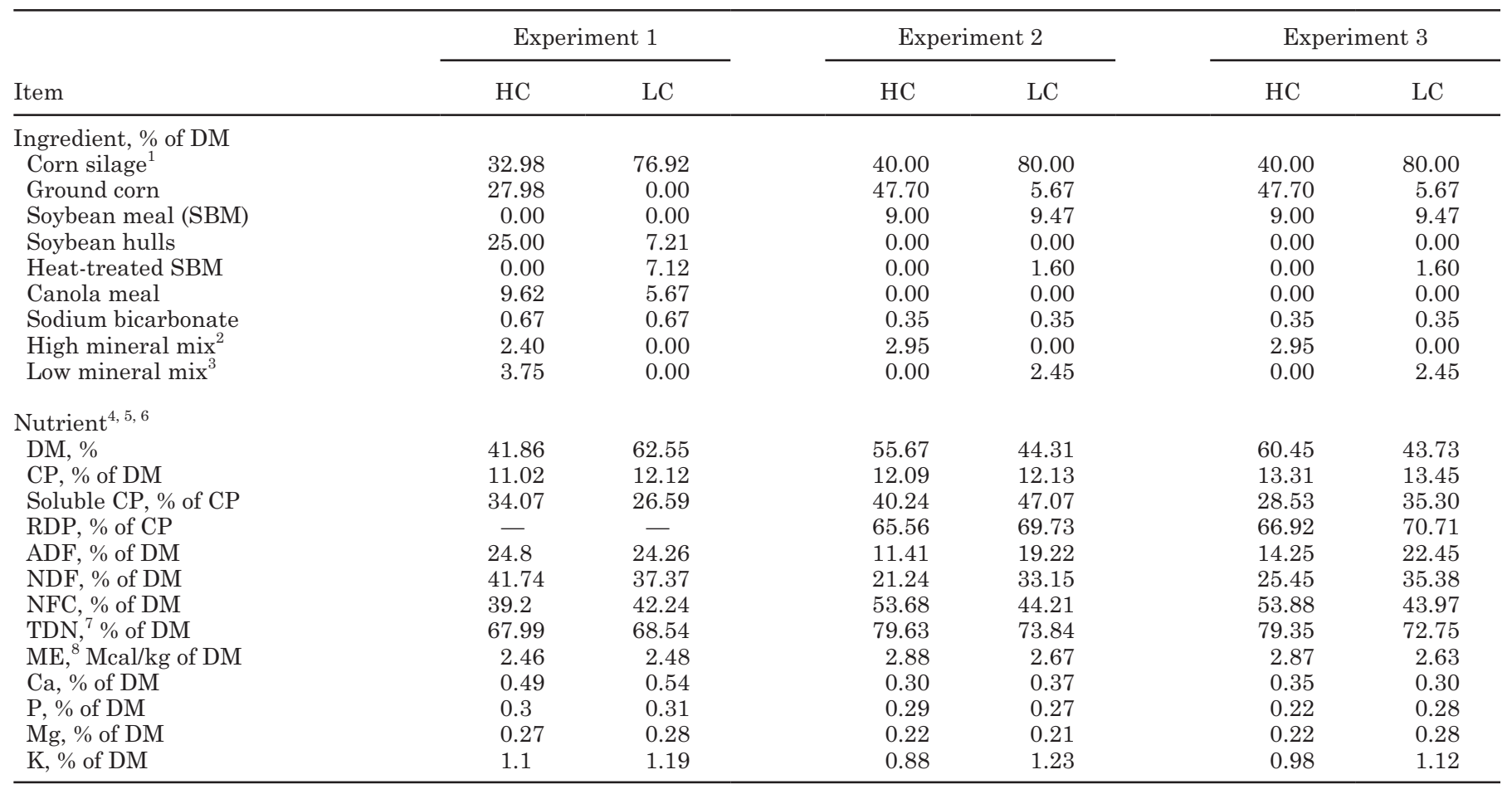

${ }^{1}$ Experiment 1: $36.05 \%$ DM, 40.63\% NDF, 24.03\% ADF, 7.27\% CP on a DM basis. Experiments 2 and 3: $34.2 \% \mathrm{DM}, 38.4 \% \mathrm{NDF}, 22.9 \% \mathrm{ADF}$, $6.78 \% \mathrm{CP}, 36.32 \%$ starch on a DM basis.

${ }^{2}$ Experiment 1: $7.4 \%$ vitamin E, $2.5 \%$ vitamins ADE, $28.6 \%$ distillers corn with soluble vitamin D, $13.9 \%$ plain salt, $34.8 \%$ limestone, $6.0 \%$ $\mathrm{Mg}$ oxide, $5.5 \%$ trace mineral premix, and 1.5\% Se premix on a DM basis. Experiments 2 and 3: 7.8\% vitamin E, 2.6\% vitamins ADE, 28.6\% distillers corn with soluble vitamin D, $14.6 \%$ plain salt, $36.5 \%$ limestone, $2.6 \% \mathrm{Mg}$ oxide, $5.7 \%$ trace mineral premix, and $1.6 \%$ Se premix on a DM basis.

${ }^{3}$ Experiment 1: 7.8\% vitamin E, 2.6\% vitamins ADE, $28.6 \%$ distillers corn with soluble vitamin D, $14.6 \%$ plain salt, $36.5 \%$ limestone, $2.6 \%$ $\mathrm{Mg}$ oxide, $5.7 \%$ trace mineral premix, and 1.6\% Se premix on a DM basis. Experiments 2 and 3: 7.4\% vitamin E, 2.5\% vitamins ADE, 28.6\% distillers corn with soluble vitamin $\mathrm{D}, 13.9 \%$ plain salt, $34.8 \%$ limestone, $6.0 \% \mathrm{Mg}$ oxide, $5.5 \%$ trace mineral premix, and $1.5 \%$ Se premix on a DM basis.

${ }^{4} \mathrm{n}=11$, samples taken daily and composited every $15 \mathrm{~d}$ for the duration of experiment 1.

${ }^{5} \mathrm{n}=9$, samples taken daily and composited every $15 \mathrm{~d}$ for the duration of experiment 2 .

${ }^{6} \mathrm{n}=10$, composite samples of 42 samples/treatment taken daily throughout the collection periods (experiment 3 ).

${ }^{7}$ Total digestible nutrients.

${ }^{8}$ Estimated: $\mathrm{ME}=\mathrm{TDN} \times 0.04409 \times 0.82$.

$$
\begin{gathered}
\mathrm{Y}_{\mathrm{ijkl}}=\mu+\mathrm{H}_{\mathrm{i}}+\mathrm{R}_{\mathrm{j}}+\mathrm{P}_{\mathrm{k}}(\mathrm{R})_{\mathrm{j}}+\mathrm{T}_{1}+\mathrm{L}_{\mathrm{m}}+(\mathrm{R} \times \mathrm{T})_{\mathrm{jl}} \\
+(\mathrm{R} \times \mathrm{L})_{\mathrm{jm}}+(\mathrm{T} \times \mathrm{L})_{\mathrm{lm}}+(\mathrm{R} \times \mathrm{T} \times \mathrm{L})_{\mathrm{jlm}}+\mathrm{e}_{\mathrm{ijk} \mathrm{km}},
\end{gathered}
$$

where $\mu$ is the overall mean; $\mathrm{H}_{\mathrm{i}}$ is the fixed effect of period ( $\mathrm{i}=1$ to 5 ); $\mathrm{R}_{\mathrm{j}}$ is the fixed effect of treatment ( $\mathrm{j}=1$ to 2$) ; \mathrm{P}_{\mathrm{k}}(\mathrm{R})_{\mathrm{j}}$ is the random effect of pen within treatment ( $\mathrm{k}=1$ to 4$) ; \mathrm{T}_{1}$ is the fixed effect of time (l= 1 to 8$) ; \mathrm{L}_{\mathrm{m}}$ is the fixed effect of location ( $\mathrm{m}=1$ to 9$)$; ( $\mathrm{R}$ $\times T)_{j 1}$ is the effect of the interaction of $R_{j}$ and $T_{1} ;(R \times L)$ ${ }_{j m}$ is the effect of the interaction of $\mathrm{R}_{\mathrm{j}}$ and $\mathrm{L}_{\mathrm{m}}$; $(\mathrm{T} \times \mathrm{L})_{\mathrm{lm}}$ is the effect of the interaction of $\mathrm{T}_{1}$ and $\mathrm{L}_{\mathrm{m}} ;(\mathrm{R} \times \mathrm{T} \times \mathrm{L})$ ${ }_{j} \mathrm{~lm}$ is the effect of the interaction of $\mathrm{R}_{\mathrm{j}}, \mathrm{T}_{\mathrm{l}}$, and $\mathrm{L}_{\mathrm{m}}$; and $\mathrm{e}_{\mathrm{ijklm}}$ is residual error.
Heifers were randomized across pens and pens were randomized across diets. Main effects and interactions were tested by using the residual error. Eight time points were measured $(1,4,7,10,25,28,31,34 \mathrm{~h})$ after the last scraping of the pens. For the first experiment, location was not included in the model because the same location was sampled at every time point. All dependent variables of the digestibility experiment were analyzed as a $4 \times 4$ Latin square design. A splitplot design was used, with age as the whole plot and diet treatment as the subplot. Sources of variation associated with fixed design effects of period and fixed treatment effects of age category, F:C and $\mathrm{YC}$ addition, and their interaction with period as the repeated effect 


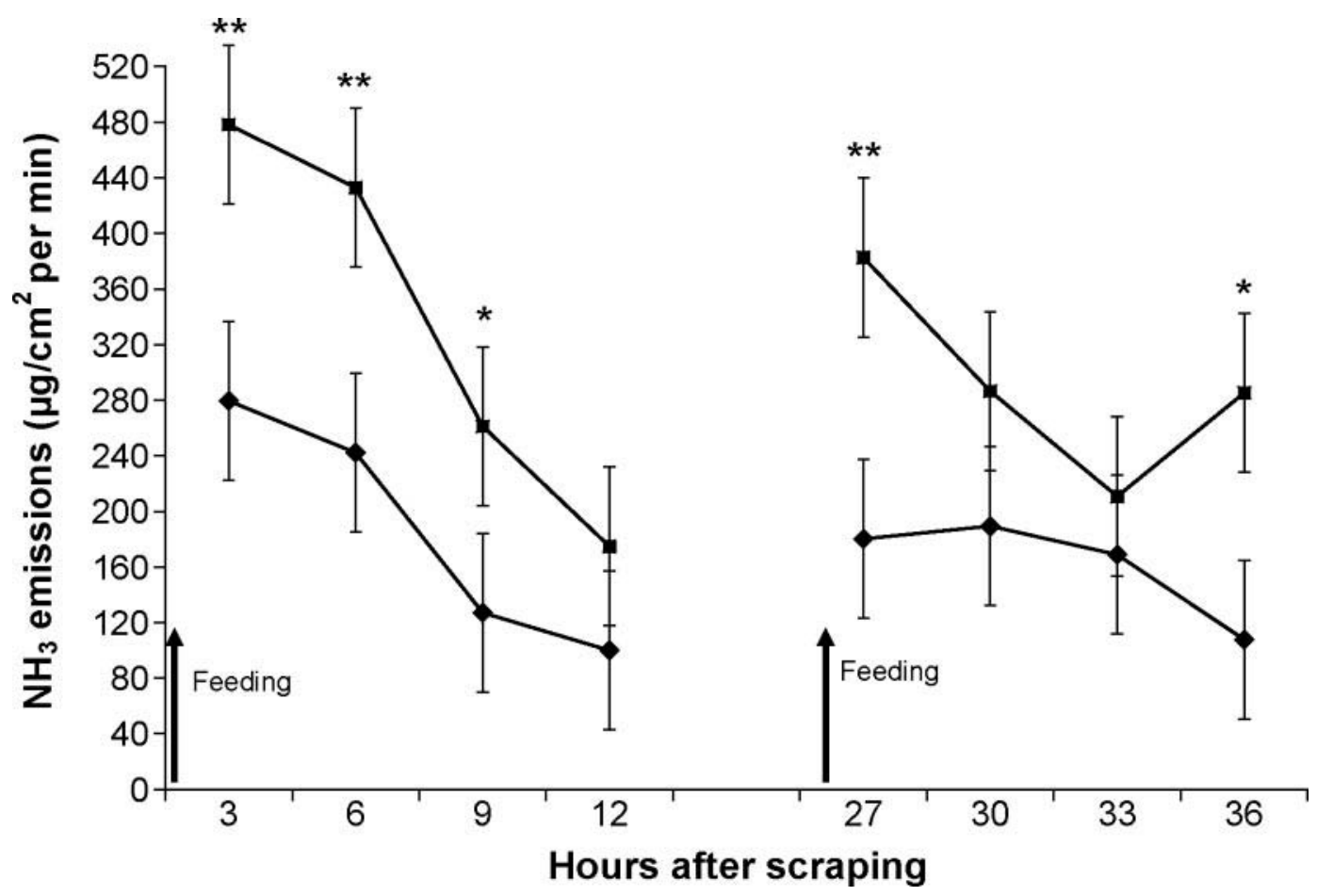

Figure 1. Ammonia emissions from the barn floor housing dairy heifers fed high-concentrate $(\bullet)$ and low-concentrate $(\boldsymbol{\bullet})$ diets in experiment 1 over a 36 -h period. Arrows indicate feeding times at 2 and $26 \mathrm{~h}$ after scraping. Bars on the graph indicate standard errors. ${ }^{* *} P<0.05$; ${ }^{*} P<0.10$.

were used. Heifer within age was included as a random effect and repeated measurements were analyzed by using the first-order autoregressive covariance structure (Littell et al., 1998). Residual variances were assumed to be normally distributed, and all data are presented as the least squares means. For all data, treatment effects were considered significant when $P<0.05$.

Ingredients and nutrient composition of treatment rations are given in Table 1 for the 3 experiments. All experiments used corn silage as the sole forage source, and diets used in the second and third experiment were the same. In experiment 1, manure from pens with heifers receiving $\mathrm{LC}$ diets had numerically greater $\mathrm{NH}_{3}$ volatilization than did manure from HC heifers (314.0 vs. 174.4 ; $\mathrm{SE}=36.1 \mathrm{\mu g} / \mathrm{cm}^{2}$ per $\min ; P=0.11$ ).

In the second experiment, there was no difference between $\mathrm{LC}$ or $\mathrm{HC}$ heifers in $\mathrm{NH}_{3}$ emissions (322 vs. 290; $\mathrm{SE}=92 \mu \mathrm{g}$ of $\mathrm{NH}_{3} / \mathrm{cm}^{2}$ per min; $P=0.81$ ). In the first experiment, the sampled part of the pen avoided areas closest to the feed bunk or the adjacent pen, which resulted in lower emissions than in the second experiment, in which the whole pen was sampled. It is important to note that the whole-pen measurement is more representative but that the same emission pattern was followed in both experiments. There was a time effect in both experiments, and emissions were higher after heifers were fed $(P<0.01$; Figures 1 and 2). Possible explanations could be that the mixture of feed with slurry increased $\mathrm{NH}_{3}$ emissions from the pen area. In addition, greater amounts of manure were produced while heifers were standing by the feed bunk; thus, emission rate was greater at this time for both treatments. The tendency of the $\mathrm{HC}$ diets to reduce $\mathrm{NH}_{3}$ volatilization in both of the experiments is partially explained by the lower DMI of the HC heifers (5.7 vs. $4.8 \mathrm{~kg} ; \mathrm{SE}=0.10 ; P<0.01$ and 5.5 vs. $5.3 \mathrm{~kg} ; \mathrm{SE}=$ $0.46 ; P=0.09)$.

Table 2 presents the results for the digestibility study, in which $\mathrm{NH}_{3}$ emissions from manure slurries were greater on a unit of manure basis for the $\mathrm{HC}$ diets $(P<0.01)$. Nitrogen intake was not different among treatments (Table 2). However, NFC content was greater for the $\mathrm{HC}$ diets (Table 1). Increasing dietary NFC has been shown to affect microbial N metabolism by increasing starch fermentation in the large intestine (Clark et al., 1992). As a result, more blood urea $\mathrm{N}$ can be recycled into microbial $\mathrm{N}$, shifting $\mathrm{N}$ excretion from urine to feces (Knowlton et al., 1998). According to this, less urea would be readily available for volatilization with the use of $\mathrm{HC}$ diets. However, in the present study, changes in the ratio of feces to urine $(P<0.01)$ resulted from a reduced fecal excretion by heifers consuming the 


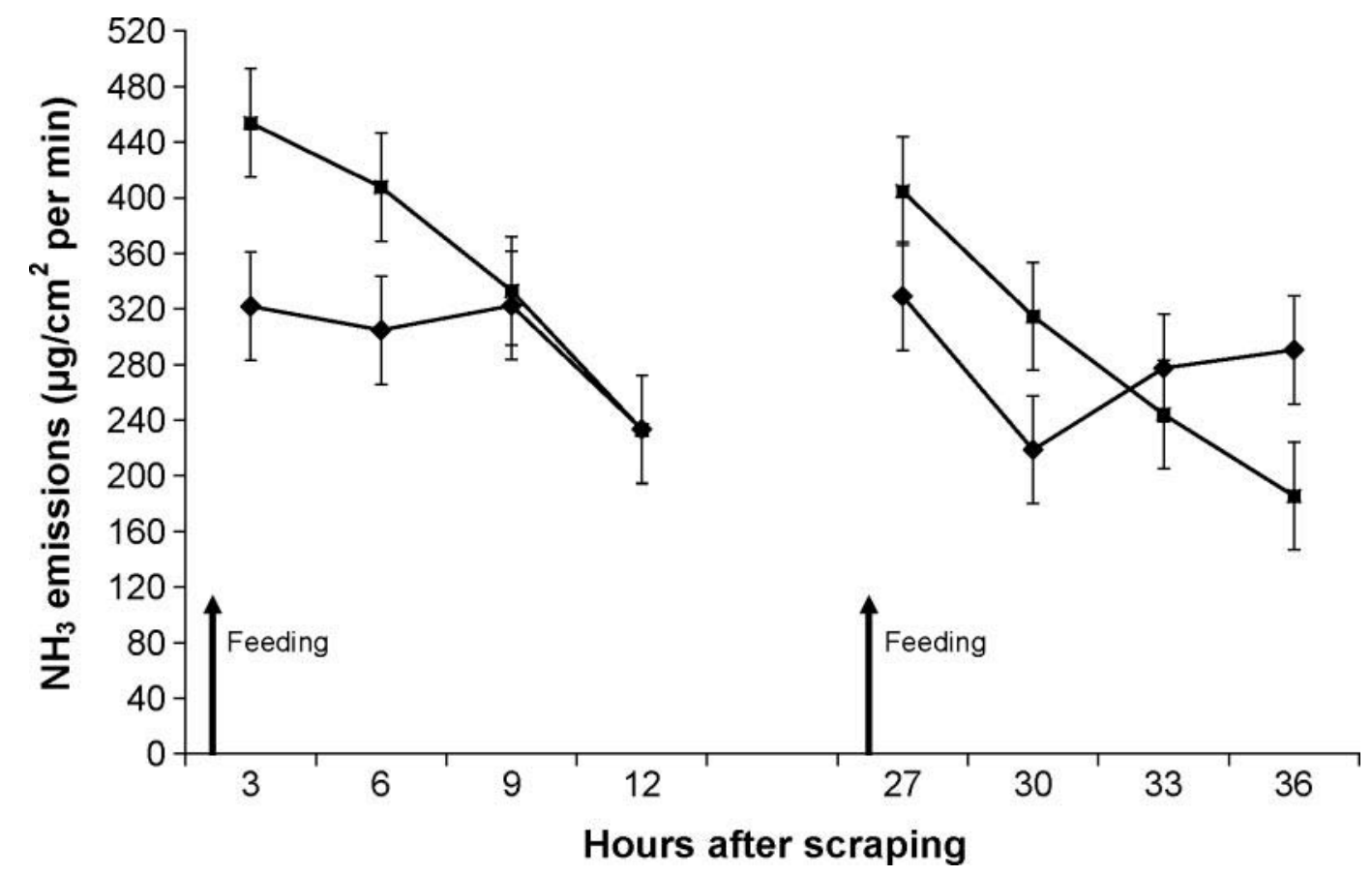

Figure 2. Ammonia emissions from the barn floor housing dairy heifers fed high-concentrate $(\downarrow)$ and low-concentrate ( $\mathbf{\square})$ diets in experiment 2 over a 36 -h period. Arrows indicate feeding times at 2 and $26 \mathrm{~h}$ after scraping. Bars on the graph indicate standard errors.

HC diet. Thus, more urinary urea per unit of manure (Table $2 ; P<0.01$ ) was available to be hydrolyzed by the urease present in feces (Misselbrook et al., 2005). It is important to note that water intake did not have an effect on the greater feces:urine of the HC group, because it was similar between animals fed the $\mathrm{HC}$ or LC diet (Table 2). As hypothesized from the results for the first 2 experiments, less total manure (g/d) was excreted by heifers fed the HC diets (Moody et al., 2007) as a result of a reduction in DMI (Table 2). In addition, total $\mathrm{NH}_{3}$ emissions were not different when reported for a 24 -h period (19.67 vs. 19.07 , and 11.94 vs. $11.52 \mathrm{~g}$ of $\mathrm{NH}_{3} / \mathrm{d} ; P=0.44$ ) for $\mathrm{HC}$ and $\mathrm{LC}$ in the 2 age groups. This is particularly important on a farm level, because it shows that there is no difference in $\mathrm{NH}_{3}$ released to the environment on a daily basis when feeding $\mathrm{HC}$ diets with the advantage of a reduced quantity of manure to be handled. Moreover, these results are in agreement with Powell et al. (2008). These researchers used group animal chambers to monitor $\mathrm{NH}_{3}$ emissions of dairy heifers of approximately $400 \mathrm{~kg}$.; emissions ranged from 10.1 to $21 \mathrm{~g}$ of $\mathrm{NH}_{3} / \mathrm{d}$, depending on the season or bedding used. This demonstrates that simulation and laboratory models can be used to asses the effects of dietary and management changes in animal husbandry. However, caution should be taken when interpreting these results, because dietary changes can have an impact on $\mathrm{NH}_{3}$ released to the environment and differ- ent forage-based diets have reported higher emissions (James et al., 1999).

Finally, YC addition had no effect on total daily $\mathrm{NH}_{3}$ emissions, but resulted in greater emissions per unit of manure $(P<0.01)$. The primary hypothesis to explain these results was an increase in urinary urea- $\mathrm{N}$ excretion. It has been shown that $\mathrm{NH}_{3}$ concentrations in the rumen decreased with $\mathrm{YC}$ supplementation, suggesting increased microbial activity (Dawson et al., 1990) and $\mathrm{NH}_{3}$ uptake by bacteria (Chaucheyras-Durand and Fonty, 2001). However, urinary urea-N excretion in the present study was not different among treatments. It is possible that as a result of increased digestibility (Wohlt et al., 1991), less fecal output was obtained by the inclusion of $\mathrm{YC}$, mimicking the effect of changing the feces:urine ratio found in the $\mathrm{HC}$ diets.

In summary, $\mathrm{NH}_{3}$ emissions from $\mathrm{HC}$ diets were not different from LC diets when measured from the barn floor in experiments 1 and 2. Ammonia emissions were greater when they were measured while heifers were eating, and the same emission pattern was followed in both growth studies. In the digestibility study, emissions from slurries of manure from heifers fed the $\mathrm{HC}$ diet showed greater emission rates per unit of manure. The fact that HC diets resulted in less DMI and a subsequent reduction in fecal output affected the feces to urine ratio. The shift in this ratio affected $\mathrm{NH}_{3}$ emissions on a per-gram basis, whereas the total manure 
produced affected daily emissions. Cumulative daily emissions were not different between diets, which concurs with the results found in experiments 1 and 2 and with the $\mathrm{YC}$ addition.

\section{REFERENCES}

Battye, R., W. Battye, C. Overcash, and S. Fudge. 1994. Development and Selection of Ammonia Emission Factors. Final report prepared for U.S. Environmental Protection No. EPA/600/R-94/190. US Environmental Protection Agency, Washington, DC.

Blanes-Vidal, V., E. F. Topper, and E. F. Wheeler. 2007. Validation of ammonia emissions from dairy cow manure estimated with a non-steady-state, recirculation flux chamber with whole-building emissions. Trans. ASABE 50:633-640.

Chaucheyras-Durand, F., and G. Fonty. 2001. Establishment of cellulolytic bacteria and development of fermentative activities in the rumen of gnotobiotically-reared lambs receiving the microbial additive Saccharomyces cerevisiae CNCM I-1077. Reprod. Nutr. Dev. 41:57-68.

Clark, J. H., T. H. Klusmeyer, and M. R. Cameron. 1992. Microbial protein synthesis and flows of nitrogen fractions to the duodenum of dairy cows. J. Dairy Sci. 75:2304-2323.

Dawson, K. A., K. E. Newman, and J. A. Boling. 1990. Effects of microbial supplements containing yeast and lactobacilli on roughage-fed ruminal microbial activities. J. Anim. Sci. 62:4348.

Fellner, V., M. F. Weiss, A. T. Belo, R. L. Belyea, F. A. Martz, and A. H. Orma. 1988. Urine cup for collection of urine from cows. J. Dairy Sci. 71:2250-2255.

James, T., D. Meyer, E. Esparza, E. J. DePeters, and H. Perez-Monti. 1999. Effects of dietary nitrogen manipulation on ammonia volatilization from manure of Holstein heifers. J. Dairy Sci. 82:2430-2439.

Knowlton, K. F., B. P. Glenn, and R. A. Erdman. 1998. Performance, ruminal fermentation, and site of starch digestion in early lactation cows fed corn grain harvested and processed differently. J. Dairy Sci. 81:1972-1984.

Littell, R. C., P. R. Henry, and C. B. Ammerman. 1998. Statistical analysis of repeated measures data using SAS procedures. J. Anim. Sci. 76:1216-1231.

Misselbrook, T. H., J. M. Powell, G. A. Broderick, and J. H. Grabber. 2005. Dietary manipulation in dairy cattle: Laboratory experiments to assess the influence on ammonia emissions. J. Dairy Sci. 88:1765-1777.

Moody, M. L., G. I. Zanton, J. M. Daubert, and A. J. Heinrichs. 2007. Nutrient utilization of differing forage-to-concentrate ratios by growing Holstein heifers. J. Dairy Sci. 90:5580-5586.

NRC. 2001. The Nutrient Requirements of Dairy Cattle. 7th rev. ed. Natl. Acad. Press, Washington, DC.

Powell, J. M., T. H. Misselbrook, and M. D. Caster. 2008. Season and bedding impacts on ammonia emissions from tie-stall dairy barns. J. Environ. Qual. 37:7-15.

USDA, National Agricultural Statistics Service. 2007. Cattle. http://usda.mannlib.cornell.edu/MannUsda/viewDocumentInfo. do?documentID=1017 Accessed Jan. 30, 2008.

Wheeler, E. F., P. A. Topper, N. E. Brown, and G. A. Varga. 2007a Multiple-chamber steady-state gas emission detection from dairy manure slurry. Pages 10-12 in Proc. Int. Symp. Air Quality and Waste Management for Agric., Broomfield, CO. Am. Soc. Agric Biol. Eng., St. Joseph, MI.

Wheeler, E. F., P. A. Topper, and T. L. Richard. 2007b. Validation of flux chamber technique for estimating gas emission in situ from naturally-ventilated facilities. Pages 10-12 in Proc. Int. Symp. Air Quality and Waste Management for Agric., Broomfield, CO. ASABE, St. Joseph, MI.

Wohlt, J. E., A. D. Finkelstein, and C. H. Chung. 1991. Yeast culture to improve intake, nutrient digestibility, and performance by dairy cattle during early lactation. J. Dairy Sci. 74:1395-1400. 